\title{
Changes in physiological parameters and feeding behaviour of Atlantic salmon Salmo salar infected with sea lice Lepeophtheirus salmonis
}

\author{
Leigh H. J. Dawson ${ }^{1, *}$, Alan W. Pike ${ }^{2}$, Dominic F. Houlihan ${ }^{2}$, Alasdair H. McVicar ${ }^{3}$ \\ ${ }^{1}$ Station Méditerranéene de l'Environnement Littoral, Université Montpellier II, 1 Quai de la Daurade, F-34200 Sète, France \\ ${ }^{2}$ Department of Zoology, University of Aberdeen, Tillydrone Avenue, Aberdeen, AB24 2TZ, Scotland, UK \\ ${ }^{3}$ SOAEFD Marine Laboratory, PO Box 101, Victoria Road, Torry, Aberdeen, AB11 9DB, Scotland, UK
}

\begin{abstract}
Atlantic salmon Salmo salar L. artificially infected with salmon lice Lepeophtheirus salmonis (Krøyer 1837) recovered from detrimental physiological changes and skin damage induced by preadult lice as the parasites matured. Growth rates of Atlantic salmon remained unaffected by lice infection, but food consumption decreased with increasing feeding and movement of the lice prior to and post-mating, correlating with the appearance of head erosions and detrimental changes in physiological integrity. Food consumption of the fish increased as the lice moulted to the adult stage and gravid female lice settled in a posterior location on the fish, subsequently reducing the impact of infection and allowing recovery of the skin damage. However, the impact of preadults was limited, as the decrease in food consumption of fish at $21 \mathrm{~d}$ post-infection had no effect on either the specific growth rate or condition factor of the fish. Furthermore, the intensity of lice infections at each of the sample days was not correlated with food consumption, specific growth rate or any of the haematological or physiological parameters measured, either before or after infection, indicating that lice intensity was independent of social dominance/subordinance. This work has provided the first evidence that infected fish can recover from the detrimental changes caused by lice infection, even when they are still infected with lice. If fish can survive the preadult stage of lice, then the mortal impact of lice infections is greatly reduced
\end{abstract}

KEY WORDS: Atlantic salmon - Feeding behaviour · Physiology Sea lice $\cdot$ Skin damage

\section{INTRODUCTION}

During the last $10 \mathrm{yr}$, the populations of both wild Atlantic salmon Salmo salar L. and sea trout Salmo trutta L. in the north Atlantic have fallen (Anonymous 1991, Berland 1993). Furthermore, at the end of the 1980s, an unpredicted sharp decline in the sea trout runs in Scotland coincided with the almost complete collapse of the sea trout stocks in western Ireland (Anonymous 1991) and a decrease in Atlantic salmon runs in Norway (Berland 1993). The cause of this phenonomen is currently unknown but the main feature of the salmonid stock decline is the early return to the

\footnotetext{
•E-mail: ldawson@crit.univ-montp2.fr
}

rivers of emaciated sea trout heavily infected with juvenile salmon lice Lepeophtheirus salmonis (Krøyer 1837) (Anonymous 1991). As farmed Atlantic salmon production expanded, the levels of lice on the farms rose dramatically, instigating debate as to whether lice from salmon farms causes mortality of wild fish or lice infections of wild salmonids are a secondary attribute to a multifactorial problem (Anonymous 1991). Little direct evidence exists to support either hypothesis and there is limited information available to help to understand the effects of lice in their host.

Much of the published information on lice infections in salmonids relies on observations of the gross pathology caused by the parasite, particularly on Atlantic salmon. In addition, some data exist on the physiological changes induced by artificially infected Atlantic 
salmon which suggest that pre-adult lice cause physiological changes in the host leading to osmoregulatory failure and mortality (Grimnes \& Jakobsen 1996). However, there are no published data on either the skin damage or physiological impact caused by the attached or adult stages of lice on naturally or experimentally infected salmonids, both of which may lead to osmoregulatory failure.

This study aimed to determine how, and to what extent, lice infections cause mortality of Atlantic salmon and the physiological consequences of and changes in feeding behaviour resulting from lice infections. Osmoregulation relies on plasma osmolality and electrolyte concentrations being maintained within relatively narrow limits, and variations from this in lice-infected fish may lead to decreased growth/ appetite in the long term. Tank experiments principally have provided information on feeding behaviour of cultured fish species (Jørgensen \& Jobling 1990, 1992. McCarthy et al. 1993a, b). The present study determined if there was a causal link between the physiological effects and food consumption in liceinfected sea trout and attempted to relate physiological changes in infected Atlantic salmon to parasite-stage specific pathology.

\section{MATERIALS AND METHODS}

Maintenance of fish. Atlantic salmon post-smolts, derived from mixed parentage Scottish farmed stocks were held in circular tanks (1 $\mathrm{m}$ diameter, $400 \mathrm{l}$ with a continual flow of aerated seawater). The experiment was carried out in duplicate (Replicate $1, n=40$ and Replicate $2, n=80$ ), using identical experimental protocols. Replicate 1 gave a preliminary data set and the experiment was repeated in duplicate in Replicate 2 in order to give a total of 3 sets of data for each manipulation. Both groups of fish in the replicate experiments were maintained under natural photoperiod and ambient seawater temperature $\left(13.9\right.$ to $\left.16.0^{\circ} \mathrm{C}\right)$ and salinity $(32 \%$ ).

After an acclimation period of $3 \mathrm{wk}$, the fish were anaesthetised $\left(0.1 \mathrm{~g} \mathrm{l}^{-3}\right)$ (MS-222, Sigma), measured for fork length ( $\mathrm{mm})$, wet weighed $(\mathrm{g})$ and randomly divided into 4 tanks (Replicate 1) or 8 tanks (Replicate 2 ). The fish were identified by a code of alcian blue marks on the ventral surface (Johnstone 1981) and fed a repelleted commercial smolt pellet diet (McCarthy et al. 1993a) at $0.5 \%$ body weight $\mathrm{d}^{-1}$ for $2 \mathrm{~h}$, between 09:00 and 11:00 h using $24 \mathrm{~h}$ clock belt feeders throughout the experiment.

Two mortalities in Replicate 1 occurred before infection with lice. In Replicate 2, mortalities occurred in 2 of the groups of fish at an early stage in the study and therefore these groups were excluded from the rest of the experiment.

Measurement of individual food consumption. The individual food consumption for each fish in 4 tanks (Replicate 1) or 6 tanks (Replicate 2) was monitored on 3 occasions prior to infection using a modification of the radiographic technique described by Talbot \& Higgins (1983). On the day that individual food consumption was measured, the fish were fed a repelleted diet containing ballotini glass spheres (400 to $520 \mu \mathrm{m}, 2 \%$ $w / w$, Jencons Scientific Ltd.) under the same regimes as for the non-ballotini diet. Two hours after feeding had ceased, the fish were anaesthetised, fork length measured, wet weighed and x-rayed using a portable x-ray machine (Todd Research Model 20/80) and Kodak Industrex CX film. Blood was collected from the fish by puncture of the caudal vein with a $0.6 \times 23 \mathrm{~mm}$ needle and a $1 \mathrm{~mm}$ syringe, centrifuged at $10000 \times g$ for 15 min and stored at $-70^{\circ} \mathrm{C}$. After recovery, the fish were returned to their respective tanks.

The $x$-ray films were developed and the number of glass beads in the alimentary tract were counted using a fluorescent-light viewing screen. Chi-squared goodness of fit tests were performed on the labelled subsamples of food and the number of ballotini glass beads in any given sample of food were shown to be Poisson distributed ( $p>0.05$ ) (Stead et al. 1996). Pearson's standardised residuals were calculated against the expected number of ballotini beads. Examination of the standardised residuals against the expected number of ballotini showed that there was no pattern in the effects and confirmed the number of ballotini fitted the Poisson distribution and that the ballotini was evenly distributed throughout the food $\left(\chi^{2} ; p>0.05\right)$.

By $x$-raying previously weighed sub-samples of the ballotini-labelled food ( 0.1 to $5.0 \mathrm{mg}$ dry food), a regression equation, relating wet weight of food consumed and the number of ballotini, was calculated (McCarthy et al. 1993a). The point at which the regression line crossed the $y$-axis was not significantly different from zero $(p>0.05)$ and therefore the regression line was forced through the origin to obtain the equation used to calculate the dry weight of consumed food:

Replicate 1: dry weight of food $(\mathrm{mg})=0.0121 \times$ number of ballotini beads

Replicate 2: dry weight of food $(\mathrm{mg})=0.0071 \times$ number of ballotini beads

Artificial infection and sampling procedure. Ovigerous adult female lice with dark, mature eggstrings were collected from farmed Atlantic salmon from cages on the west coast of Scotland. The lice were removed with forceps as the fish were harvested, primarily from the area posterior to the adipose fin on the dorsal surface and the anal fin on the ventral surface, 
and placed in plastic containers filled with fresh seawater from the site $\left(12^{\circ} \mathrm{C}\right.$ and $32 \%$ ). The containers were packed in ice and transported to Aberdeen University for rearing to the infective copepodid stage.

One hundred copepodids per fish were introduced to the water of 3 tanks of fish (Replicate 1 ) and 5 tanks of fish (Replicate 2) under conditions of high aeration and no water flow. After $3 \mathrm{~h}$, the water flow was resumed and the aeration removed. Control groups (1 tank in Replicate 1 and 1 tank in Replicate 2) were treated the same as the experimental groups but without introduction of copepodids.

Twelve days post-infection (p.i.), $21 \mathrm{~d}$ p.i. and $30 \mathrm{~d}$ p.i. 1 group of infected fish and 1 group of control fish from Replicate 1 and 1 group of control and either 1 or 2 groups of infected fish from Replicate 2 were fed the ballotini diet, and $2 \mathrm{~h}$ after feeding had ceased, the fish were anaesthetised, weighed, measured and x-rayed. The infected groups were sacrificed by a lethal dose of anaesthetic and the number and developmental stage of the lice were recorded for each fish

The position of lice on each fish was determined for the fins, gills and 7 regions of the body surface: head region, posterior ventral from the caudal fin to the anal fin, mid-ventral from the pectoral fins to the pelvic fins, anterior ventral from the pectoral fins to the head, all below the lateral line; posterior dorsal from the caudal fin to the adipose fin, mid-dorsal from the adipose fin to the dorsal fin and anterior dorsal from the caudal fin to the head, all above the lateral line. Dorsal fin erosion was estimated by eye, grouped into 4 arbitrary categories $(0=$ no dorsal fin erosion, $1=<33 \%$ of the dorsal fin eroded, $2=>33<66 \%$ dorsal fin erosion, $3=>66 \%$ dorsal fin erosion) and the extent of skin damage was estimated for 3 regions of each fish, i.e. head (head and operculum), dorsal surface (dorsal ridge) and anal region (behind the anal fin), and grouped into 5 arbitrary categories (Table 1 ).

Blood was collected from the fish by puncture of the caudal vein as before and all serum was subsequently tested using a random access autoanalyser (RA-XT; Technicon) for levels of the following physiological parameters in order to indicate differences between

Table 1. Salmo salar. Categories of skin damage on Atlantic salmon

\begin{tabular}{|lcc|}
\hline Category & Head and dorsal surface & Anal region \\
\hline 0 & No grazing & No grazing \\
1 & Slight grazing & Slight grazing \\
2 & No obvious erosion but bleeding & No obvious erosion but bleeding \\
& when removed from water & When removed from water \\
3 & Open erosion and bleeding & Open erosion and bleeding \\
4 & Muscle/skull exposed & Erosion bigger than \\
& & thumbnail and bleeding \\
\end{tabular}

control and infected groups of fish: osmolarity, chloride, sodium, potassium, calcium, glucose, cholesterol, total protein, serum albumin, lactate dehygrogenase and alkaline phosphatase. Haematocrit and leucocrit were determined using the methods of McLeay \& Gordon (1977). These variables were chosen to represent the overall physiological integrity of the fish and to give an indication of the osmoregulatory capacity of the fish compared with controls.

Data manipulation and statistical analysis. Percentage moisture was determined for whole bodies of 1 group of control fish $(n=10)$ from each replicate at the end of the experiment and freeze-dried to a constant weight. The mean percentage moisture content was $73.42 \pm 0.70$ (Replicate 1) and $71.18 \pm 0.89$ (Replicate 2) and the data was used to estimate dry weights from wet weights for data interpretation and statistical analysis. Two fish moved during the $x$-ray exposure time on the second day of $x$-raying in Replicate 1 and the ballotini were difficult to count. These fish and the mortalities were excluded from the analyses.

The dry specific growth rates, SGR $\left(\% \mathrm{~d}^{-1}\right)$ (Ricker 1979), and the condition factor $(K)$ (Jørgensen \& Jobling 1994) were calculated. Food consumption for individual fish was calculated as mg dry food $\mathrm{g}^{-1}$ dry body weight $\mathrm{d}^{-1}$ (McCarthy et al. 1993a) and the percentage of feeding fish was calculated for each group. Individual food consumption before infection was based on the mean of $3 \mathrm{x}$-ray measurements, and individual consumption after infection was based on $1 \mathrm{x}$ ray measurement taken on Days 12,21 and $30 \mathrm{~d}$ p.i. All data are presented as means with their standard errors or as percentages.

Kendall's coefficient of concordance (Wilkinson 1992) was used to examine the relationship between the values of food consumption determined from the mean of $3 \mathrm{x}$-rays pre-infection and from $1 \mathrm{x}$-ray post-infection as day-to-day variation in food consumption has been widely reported (Jobling et al. 1993, McCarthy et al. 1993b). The results suggested that for each replicate, on sample Days 12 and 30, the values for food consumption post-infection were representative of the whole period but the results for Day 21 were significantly different from the mean of $3 \mathrm{x}$-rays before infection.

No significant differences were found between the replicate experiments and thus results were pooled for further analyses. Analysis of variance and Tukey tests were used to examine significant differences in mean dry food consumption, mean dry SGR, mean condition factor and the mean of each of the physiological parameters measured from fish from the replicate 
experiments, prior to infection. The same tests were used to examine differences in mean dry food consumption, mean dry SGR, mean condition factor and the mean of leucocrit, chloride, glucose, calcium and osmolarity measured from fish from the replicate groups on Days 12, 21 and 30 p.i. (except for mean dry food consumption, the remainder of the physiological parameters and haematocrit at $21 \mathrm{~d}$ p.i., for which Friedman's tests were used). Friedman's tests were used to examine differences in mean numbers of lice, lice developinental stages, lice distribution and skin damage between replicate groups on Days 12, 21 and 30 p.i.

Spearman's rank correlation coefficient tests were used to determine the relationship between the food consumption in individual fish for each group and the corresponding food consumption for that fish after infection. The same test was used to determine the relationship between either SGR or each of the physiological or haematological parameters before and after infection. Spearman's rank correlation coefficient tests were used to determine the relationship between lice intensity for individual fish and either the corresponding food consumption, SGR, physiological or haematological parameter for that fish before and after infection and also to determine the relationship between individual food consumption and all haematological and physiological parameters measured both before and after infection. Results were considered significant at $\mathrm{p}<0.05$.

\section{RESULTS}

\section{Development and distribution of lice}

No significant differences in mean number, developmental stage or distribution of lice were found between the replicate groups either within or between replicate experiments for each sample day $(\mathrm{p}>0.05)$. At $12 \mathrm{~d}$ p.i., $71.5( \pm 5.6)$ of the administered lice survived (Fig. 1). Third and fourth chalimus stages (late chalimus) (Fig. 2) were distributed on the fins $(33.4 \pm 10.1)$, gills $(1.8 \pm 1.1)$ and body (5.4 \pm 0.8 ) of the fish (Fig. 3). Preadult I males $(15.9 \pm 3.7)$ were also found $12 \mathrm{~d}$ p.i. (Fig. 3) distributed on the skin of the fish.

At $21 \mathrm{~d}$ p.i., $51.5( \pm 4.3)$ of the administered lice survived (Fig. 1). The lice had moulted mainly to preadult II male, preadult II female and adult male stages, but late chalimus, preadult I males, preadult I females and adult female stages were found also (Fig. 2). Adult male and preadult II female in pre-copulatory pairs were located primarily in the head region $(2.3 \pm 0.3)$ and recently mated females mainly were found posterior to the adipose fin on the dorsal surface $(5.5 \pm 0.6)$

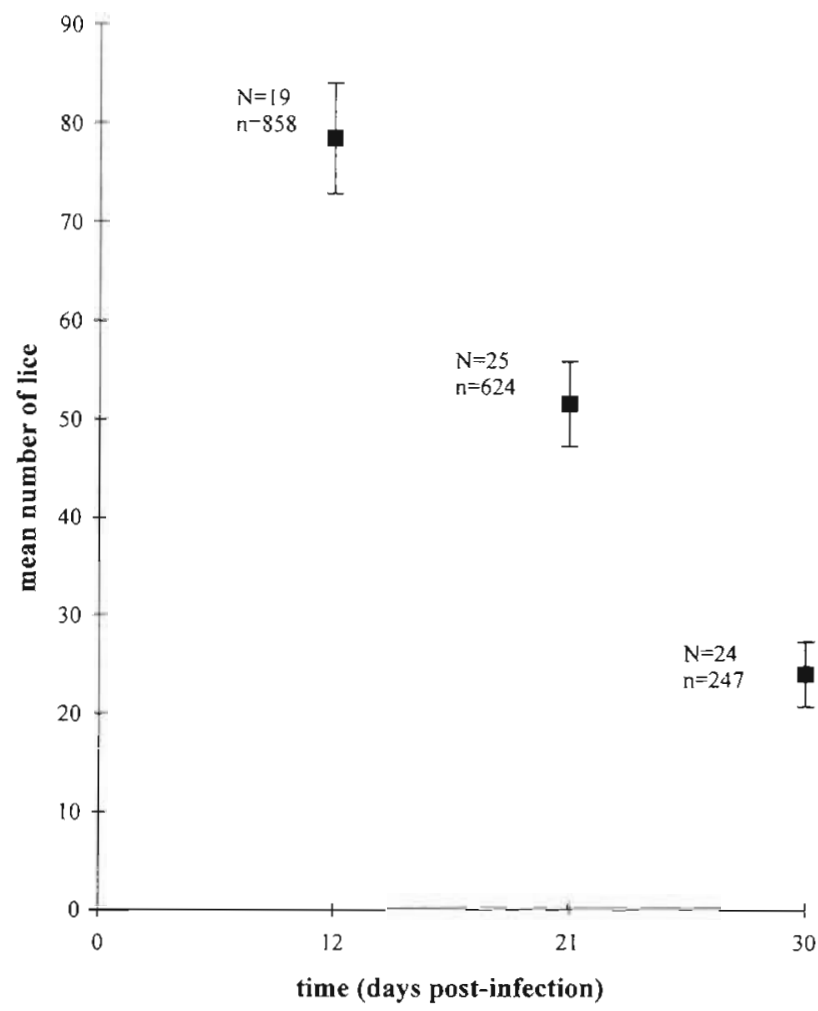

Fig. 1. Lepeophtheirus salmonis. Mean number of lice per fish on individual Atlantic salmon at $12(\mathrm{~N}=19), 21(\mathrm{~N}=25)$ and $30(\mathrm{~N}=24) \mathrm{d}$ post-infection. $\mathrm{N}=$ number of fish; $\mathrm{n}=$ total number of lice

and the anal fin on the ventral surface $(1.3 \pm 0.1)$ (Fig. 3).

At $30 \mathrm{~d}$ p.i., $24.0( \pm 3.3)$ lice survived (Fig. 1) and the lice were all adult males and adult females either unmated, mated without eggstrings or mated with eggstrings (Fig. 2). Males were found on the head of the fish $(8.4 \pm 2.3)$ and near the dorsal fin $(0.5 \pm 0.3)$ with the unmated females, and gravid females were found posterior to the adipose fin on the dorsal surface (1.8 \pm $0.6)$ and the anal fin on the ventral surface $(3.1 \pm 1.1)$ (Fig. 3).

Table 2. Salmo salar. Cumulative percentage of dorsal fin erosion for control (Con.) Atlantic salmon and lice-infected (Inf.) Atlantic salmon sampled at 12,21 and $30 \mathrm{~d}$ post-infection

\begin{tabular}{|cccccccc|}
\hline \multirow{7}{*}{ Category } & \multicolumn{7}{c}{ Percentage of fish } \\
& \multicolumn{2}{c}{$12 \mathrm{~d}$ p.i. } & \multicolumn{2}{c|}{$21 \mathrm{~d}$ p.i. } & \multicolumn{2}{c|}{$30 \mathrm{~d}$ p.i. } \\
& Con. & Inf & Con. & Inf. & Con. & Inf. \\
\hline 0 & 78.9 & 0 & 78.9 & 0 & 73.7 & 0 \\
1 & 21.1 & 31.6 & 21.1 & 20.0 & 26.3 & 29.2 \\
2 & 0 & 68.4 & 0 & 80.0 & 0 & 70.8 \\
3 & 0 & 0 & 0 & 0 & 0 & 0 \\
\hline
\end{tabular}



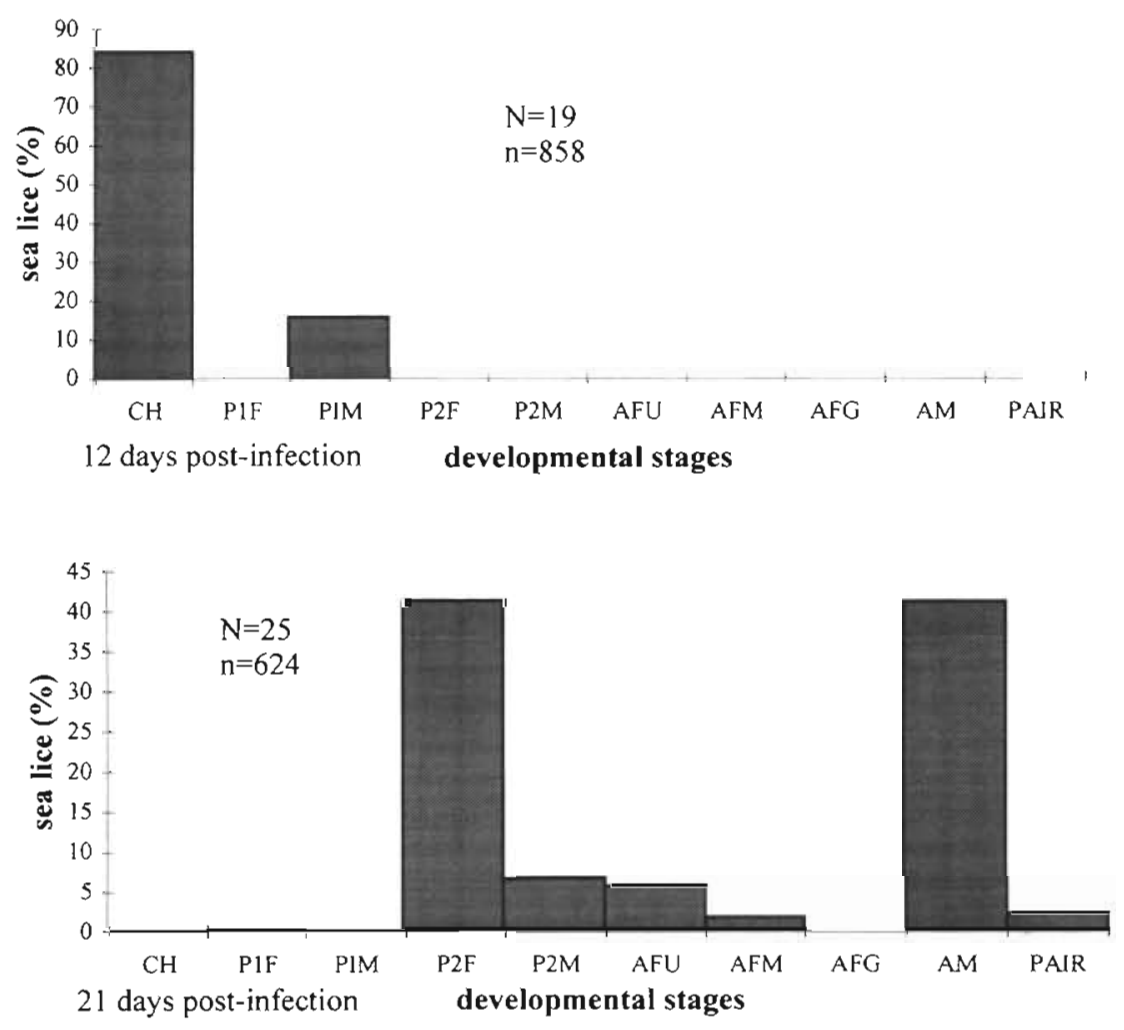

Fig. 2. Lepeophtheirus salmonis. Frequency distribution (\%) of lice developmental stages on Atlantic salmon at 12,21 and $30 \mathrm{~d}$ post-infection. $\mathrm{CH}=$ chalimus III and IV; P1F = preadult 1 female; $\mathrm{P} 1 \mathrm{M}=$ preadult 1 male; $\mathrm{P} 2 \mathrm{~F}=$ preadult 2 female; $\mathrm{P} 2 \mathrm{M}=$ preadult 2 male; $\mathrm{AFU}=$ adult female unmated $\mathrm{AFM}=$ adult female mated; $\mathrm{AFG}=$ adult female gravid; $A M$ = adult male; PAIR = precopulatory pair. $N=$ total number of fish; $n=$ total number of lice

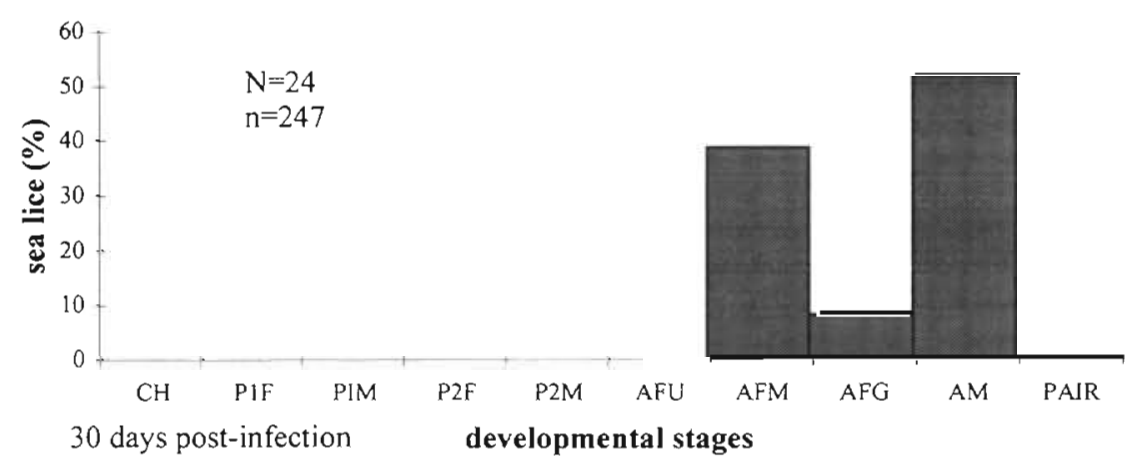

\section{Morphological damage}

Control fish had either Category 0 or 1 dorsal fin erosion and infected fish had either Category 1 or 2 dorsal fin erosion (Table 2). The cumulative pathology was not statistically significant between control or between infected groups ( $p>0.05$ ), but significantly more of the fish in the infected groups had Category 1 and 2 dorsal fin erosion compared with the control fish $(p<0.001)$.

Head, dorsal and anal region erosions were not apparent on any of the control fish and therefore, all fish in the control groups were denoted as having Category 0 erosions. The cumulative pathology was not statistically significant between infected groups $(\mathrm{p}>$ $0.05)$. No skin erosions were observed on any of the fish at 12 d p.i. Skin damage was confined to the region directly behind the head in $80 \%$ of fish in all tanks at $21 \mathrm{~d}$ p.i.; at $30 \mathrm{~d}$ p.i., although some fish had head erosions, anal erosions were evident in almost all fish, located behind the anal fin on the ventral surface of the fish. (Fig. 4).

\section{Growth parameters}

The control groups were x-rayed 6 times throughout both experiments whereas the infected fish were $x$-rayed only 4 times. However, no significant differences were found in food consumption between the 6 sampling times in the control groups ( $p>0.005)$, 

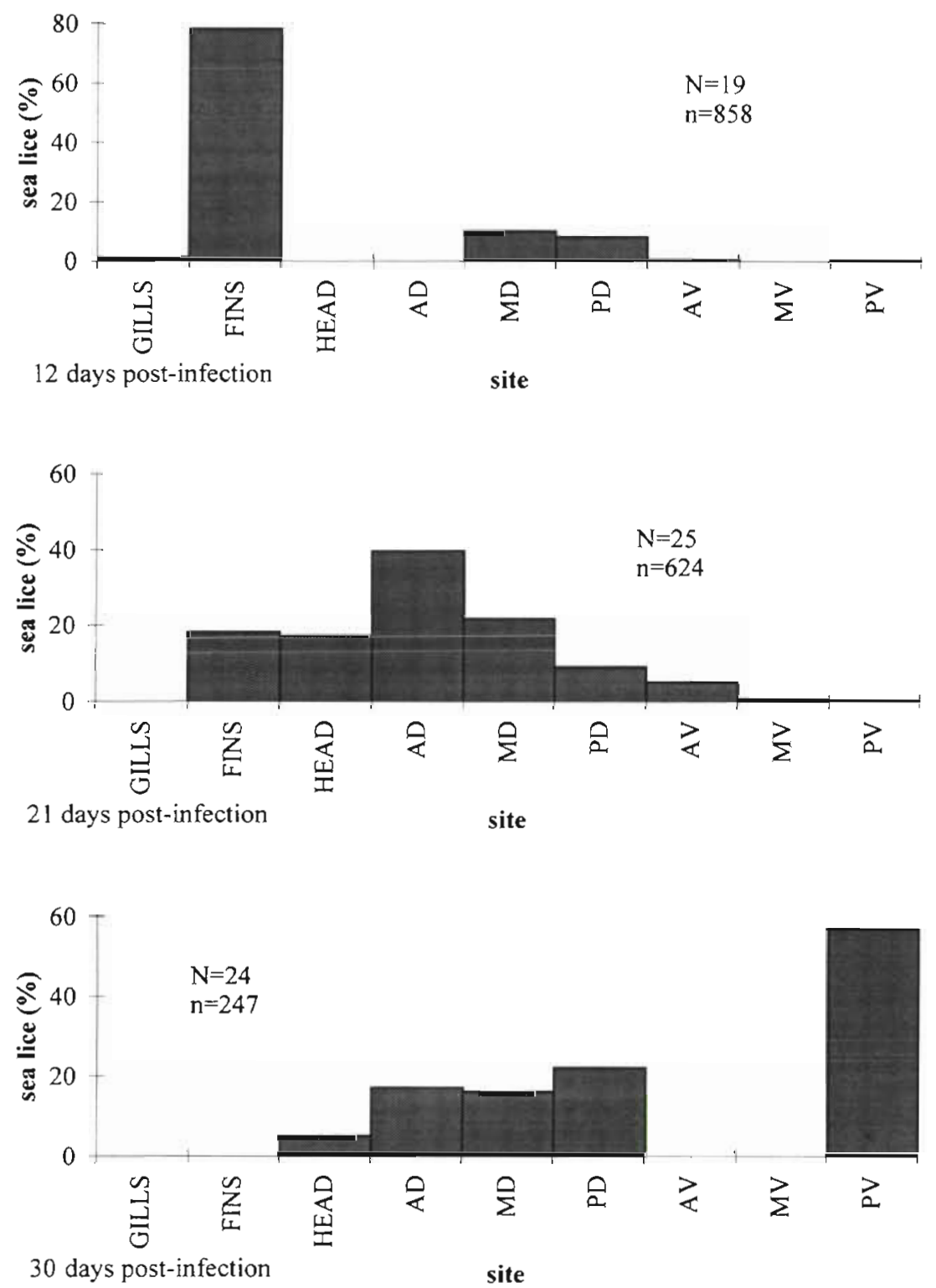

Fig. 3. Lepeophtheirus salmonis. Percentage distribution of lice on 9 body regions of Atlantic salmon at 12, 21 and $30 \mathrm{~d}$ post-infection. $\mathrm{AD}=$ anterior dorsal; $M D=$ mid-dorsal $\mathrm{PD}=$ posterior dorsal ${ }_{i} \mathrm{AV}=$ anterior ventral $\mathrm{I}_{i}$ $M V=$ mid-ventral $\mathrm{PV}=$ posterior ventral. $N=$ total number of fish; $\mathrm{n}=$ total number of lice

therefore justifying using the food consumption from these fish to compare with food consumption of the infected fish.

At the beginning of the experiment and immediately prior to infection, no significant difference was found in the mean dry weights between tanks, even though the fish were randomly allocated to tanks $(\mathrm{p}>0.05)$ (Table 3). The mean dry specific growth rates, mean dry food consumption and mean condition of all the groups also did not differ significantly before infection ( $p>0.05$ ) (Table 3).

No significant difference was found in mean dry food consumption between the control group and the experimental group sampled at $12 \mathrm{~d}$ p.i. and the group sampled 30 d p.i. ( $>>0.05$ ) (Table 4). Similarly, the differences in the mean dry specific growth rate and con- dition factor of the same groups and those fish sampled at Day 21 ( $p>0.05$ ) were not significantly different (Table 4). However, at $21 \mathrm{~d}$ p.i, the mean dry food consumption was significantly lower than that of the other groups ( $p=0.002)$ with only 8 fish within the groups feeding (Table 4).

Individual food consumption before infection was not correlated with the food consumption in the same fish after infection ( $p>0.05)$. There was no correlation between dry food consumption for individual fish, either before or after infection, and the corresponding lice intensity for the same fish $(p>0.05)$ or between individual SGR for individual fish, either before or after infection, and the corresponding lice intensity for the same fish ( $p>0.05)$ for any of the tanks post-infection. 


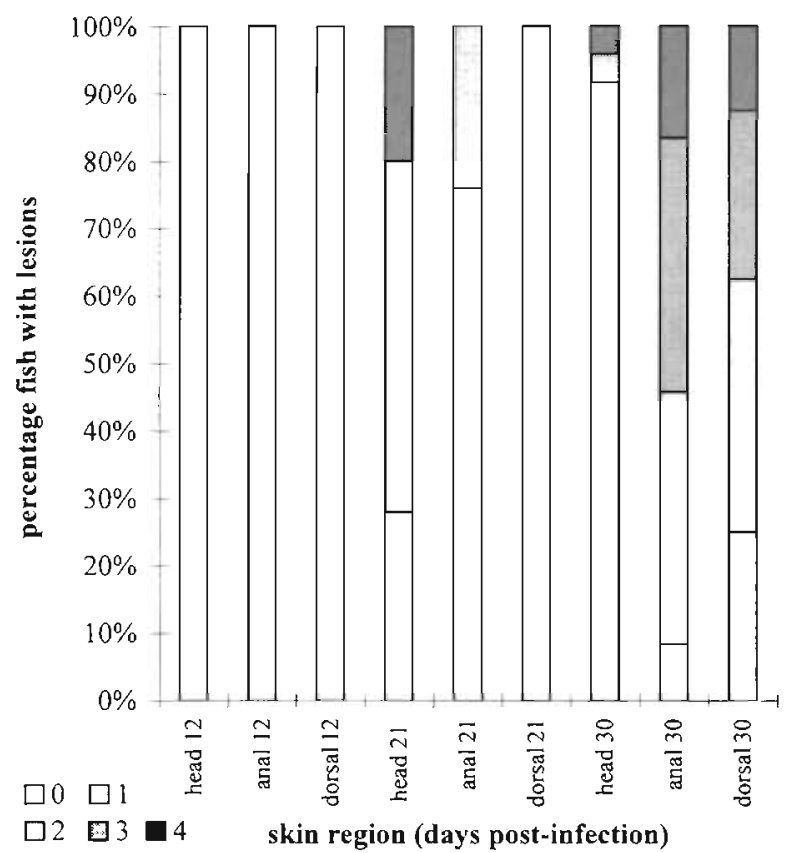

Fig. 4. Salmo salar. Percentage of Atlantic salmon with head, anal and dorsal erosion (see Table 1 for category definitions), at $12(\mathrm{~N}=19), 21(\mathrm{~N}=25)$ and $30(\mathrm{~N}=30)$ d post-infection

\section{Physiological parameters}

Before infection, there were no significant differences between the replicate groups in any of the physiological or haematological parameters measured $(p>$ $0.05)$. Similarly, at $12 \mathrm{~d}$ p.i., no significant differences were found in any of the blood parameters measured between and within infected and uninfected groups $(p>0.05)$ (Table 5). Haematocrit decreased significantly at $21 \mathrm{~d}$ p.i. $(\mathrm{p}=0.012)$ but there were no significant differences in leucocrit between any of the groups $(p>0.05)$. Similarly, osmolarity did not change significantly throughout the experiment $(p>0.05)$. Potassium increased significantly from all other groups at $21 \mathrm{~d}$ p.i. $(p=0.005)$. Sodium decreased significantly $(p=0.024)$ at Days 21 and 30 p.i. from the control and the group sampled at $12 \mathrm{~d}$ p.i. Cholesterol ( $\mathrm{p}=0.009$ ) and osmolarity $(p=0.021)$ decreased significantly from Day 12 to Day $21(p=0.009)$. Albumin $(p=0.002)$ and protein $(p=$ 0.002 ) decreased significantly from all other groups at 21 d p.i. Lactate dehygrogenase levels decreased significantly from all other groups at 21 d p.i. $(p=0.049)$, and alkaline phosphatase levels differed significantly at 21 and $30 \mathrm{~d}$ p.i. from the control and $12 \mathrm{~d}$ p.i. groups $(p=0.003)$. All parameters except sodium and alkaline phosphatase were not significantly different from the control group at $30 \mathrm{~d}$ p.i. $(\mathrm{p}>0.05)$.

Table 3. Salmo salar. Dry weights $(\mathrm{g})$, condition factor $\left(K, \mathrm{~g} \mathrm{~cm}^{-1} \times 100\right)$ b (coefficient of length against weight), specific growth rates (SGR, \% dry body weight $\mathrm{d}^{-1}$ ), mean consumption ( $\mathrm{mg}$ dry food $\mathrm{g}^{-1} \mathrm{dry}$ body weight $\mathrm{d}^{-1}$ ), and number of feeding fish for individual Atlantic salmon before infection with lice. All data are presented as means with their standard errors in parentheses. Means with the same letter were not significantly different from each other at the $5 \%$ level. Group $1=$ pooled data from all control fish from both replicate experiments; Group $2=$ pooled data all fish sampled $12 \mathrm{~d}$ post-infection; Group $3=$ pooled data all fish sampled $21 \mathrm{~d}$ post-infection; Group 4 = pooled data from all fish sampled $30 \mathrm{~d}$ post-infection

\begin{tabular}{|c|c|c|c|c|c|}
\hline & & \multicolumn{4}{|c|}{ Group of fish } \\
\hline & & Group 1 & Group 2 & Group 3 & Group 4 \\
\hline \multirow[t]{2}{*}{ No. of tanks } & Initial & 3 & 3 & 3 & 3 \\
\hline & Final & 2 & 2 & 3 & 3 \\
\hline \multirow[t]{2}{*}{ No. of fish } & Initial & 30 & 30 & 30 & 30 \\
\hline & Final & 19 & 19 & 25 & 24 \\
\hline \multirow[t]{3}{*}{ Dry weight } & $X$-ray 1 & $113.81^{\mathrm{a}}(11.71)$ & $121.02^{a}(31.37)$ & $126.21^{a}(9.63)$ & $129.22^{\mathrm{a}}(9.95)$ \\
\hline & $X$-ray 2 & $113.17^{\circ}(11.79)$ & $123.70^{\mathrm{a}}(11.54)$ & $132.34^{\mathrm{a}}(9.95)$ & $127.71^{\mathrm{a}}(9.82)$ \\
\hline & $X$-ray 3 & $113.89^{a}(11.67)$ & $128.86^{\mathrm{a}}(11.41)$ & $132.46^{d}(9.09)$ & $131.58^{\mathrm{a}}(6.74)$ \\
\hline \multirow[t]{3}{*}{$K(b=2.68)$} & $X$-ray 1 & $3.09^{\mathrm{a}}(0.08)$ & $2.89^{\mathrm{a}}(0.12)$ & $3.04^{\mathrm{a}}(0.10)$ & $3.11^{\mathrm{a}}(0.06)$ \\
\hline & $X$-ray 2 & $2.98^{\mathrm{a}}(0.07)$ & $3.01^{d}(0.10)$ & $3.08^{\mathrm{d}}(0.07)$ & $3.08^{i}(0.05)$ \\
\hline & $x$-ray 3 & $3.09^{\mathrm{a}}(0.09)$ & $3.15^{\mathrm{a}}(0.12)$ & $3.09^{\circ}(0.06)$ & $3.11^{\mathrm{a}}(0.05)$ \\
\hline \multirow[t]{3}{*}{ SGR } & $X$-ray 1 & $0.25^{\mathrm{a}}(0.19)$ & $0.37^{a}(0.28)$ & $0.41^{\mathrm{a}}(0.11)$ & $0.41^{\mathrm{a}}(0.11)$ \\
\hline & $X$-ray 2 & $0.30^{a}(0.09)$ & $0.30^{\circ}(0.12)$ & $0.24^{\mathrm{a}}(0.05)$ & $0.31^{\circ}(0.10)$ \\
\hline & $X$-ray 3 & $0.31^{a}(0.08)$ & $0.32^{\mathrm{a}}(0.11)$ & $0.28^{a}(0.05)$ & $0.30^{\circ}(0.06)$ \\
\hline \multirow[t]{3}{*}{ Consumption } & $X$-ray 1 & $3.26^{\mathrm{a}}(0.59)$ & $3.31^{\mathrm{a}}(0.72)$ & $2.95^{\mathrm{a}}(0.50)$ & $3.10^{a}(0.59)$ \\
\hline & $X$-ray 2 & $3.00^{\mathrm{d}}(0.64)$ & $2.91^{\mathrm{a}}(0.67)$ & $4.24^{\mathrm{a}}(1.12)$ & $3.16^{\mathrm{a}}(0.57)$ \\
\hline & $X$-ray 3 & $3.42^{\mathrm{a}}(0.71)$ & $3.62^{\mathrm{a}}(0.78)$ & $3.83^{\circ}(0.93)$ & $3.26^{\circ}(0.76)$ \\
\hline \multirow[t]{3}{*}{ Feeding fish } & $X$-ray 1 & 19 & 19 & 25 & 24 \\
\hline & $x$-ray 2 & 19 & 19 & 25 & 24 \\
\hline & $x$-ray 3 & 19 & 19 & 25 & 24 \\
\hline
\end{tabular}


Table 4. Salmo salar. Dry weights $(\mathrm{g})$, condition factor $\left(K, \mathrm{~g} \mathrm{~cm}^{-1} \times 100\right), b$ (coefficienct of length against weight), specific growth rates (SGR, \% dry body weight $\mathrm{d}^{-1}$ ), mean consumption ( $\mathrm{mg}$ dry food $\mathrm{g}^{-1}$ dry body weight $\mathrm{d}^{-1}$ ), and number of teeding fish after infection with lice. All data are presented as means with their standard errors in parentheses. X-ray 1 corresponds to $12 \mathrm{~d}$ postinfection, x-ray 2, $21 \mathrm{~d}$ post-infection and x-ray 3, $30 \mathrm{~d}$ post-infection. Means with the same letters were not significantly different from each other at the $5 \%$ level. Group $1=$ pooled data from all control fish from both replicate experiments ${ }_{i}$ Group $2=$ pooled data all fish sampled $12 \mathrm{~d}$ post-infection; Group 3 = pooled data all fish sampled $21 \mathrm{~d}$ post-infection; Group $4=$ pooled data from all fish sampled $30 \mathrm{~d}$ post-infection

\begin{tabular}{|c|c|c|c|c|c|}
\hline & & \multicolumn{4}{|c|}{ Group of fish } \\
\hline No. of tanks & $\begin{array}{l}\text { Initial } \\
\text { Final }\end{array}$ & $\begin{array}{l}3 \\
2\end{array}$ & $\begin{array}{l}3 \\
2\end{array}$ & $\begin{array}{l}3 \\
3\end{array}$ & $\begin{array}{l}3 \\
3\end{array}$ \\
\hline No. of fish & $\begin{array}{l}\text { Initial } \\
\text { Final }\end{array}$ & $\begin{array}{l}19 \\
19\end{array}$ & $\begin{array}{l}19 \\
19\end{array}$ & $\begin{array}{l}25 \\
25\end{array}$ & $\begin{array}{l}24 \\
24\end{array}$ \\
\hline Dry weight & $\begin{array}{l}X-\text { ray } 1 \\
X-\text { ray } 2 \\
X-\text { ray } 3\end{array}$ & $\begin{array}{l}123.75^{\star}(12.49) \\
134.24^{\star}(17.71) \\
139.23^{a}(17.82)\end{array}$ & $131.34^{\mathrm{d}}(11.51)$ & $135.54^{\mathrm{a}}(8.69)$ & $139.49^{\mathrm{d}}(9.19)$ \\
\hline$K(b=2.36)$ & $\begin{array}{l}X-\text { ray } 1 \\
X-\text { ray } 2 \\
X-\text { ray } 3\end{array}$ & $\begin{array}{l}3.09^{\mathrm{d}}(0.10) \\
3.10^{\mathrm{d}}(0.10) \\
3.00^{\mathrm{d}}(0.07)\end{array}$ & $3.00^{\mathrm{a}}(0.17)$ & $3.21^{\mathrm{d}}(0.08)$ & $3.07^{a}(0.05)$ \\
\hline SGR & $\begin{array}{l}X \text {-ray } 1 \\
X \text {-ray } 2 \\
X \text {-ray } 3\end{array}$ & $\begin{array}{l}0.29^{\mathrm{d}}(0.15) \\
0.34^{\mathrm{d}}(0.10) \\
0.36^{\mathrm{a}}(0.08)\end{array}$ & $0.40^{\mathrm{d}}(0.20)$ & $0.35^{\bar{a}}(0.06)$ & $0.26^{\mathrm{d}}(0.05)$ \\
\hline Consumption & $\begin{array}{l}X \text {-ray } 1 \\
X \text {-ray } 2 \\
X \text {-ray } 3\end{array}$ & $\begin{array}{l}4.00^{d}(0.66) \\
3.34^{d}(0.62) \\
3.60^{d}(0.56)\end{array}$ & $3.53^{\circ}(0.84)$ & $1.11^{b}(0.57)$ & $2.96^{\mathrm{a}}(0.75)$ \\
\hline Feeding fish & $\begin{array}{l}X \text {-ray } 1 \\
X \text {-ray } 2 \\
X \text {-ray } 3\end{array}$ & $\begin{array}{l}19 \\
19 \\
19\end{array}$ & 15 & 8 & 21 \\
\hline
\end{tabular}

No significant relationships were found between haematocrit and any of the other physiological parameters measured and food consumption either before or after infection ( $p>0.05$ ). No significant correlations were found between any of the physiological or haematological parameters for individual fish either before or after infection and the corresponding lice intensity for that same individual fish after infection $(p>0.05)$.

\section{DISCUSSION}

The physiological and haematological parameters measured in the fish sampled at $12 \mathrm{~d}$ p.i. in this study were not significantly different from the control groups and indicated that the damage caused by chalimus was insufficient to cause osmoregulatory failure. The impact of the chalimus is restricted to the size of the radial area around the frontal filament attachment point (Pike 1989) and the associated erosion is limited to this area. Grimnes \& Jakobsen (1996) reported that preadult stages of lice cause osmoregulatory failure and the results from the present work confirm that chalimus do not cause osmoregulatory breakdown leading to mortality.

At $21 \mathrm{~d}$ p.i., when the lice mainly were preadults, a decrease in the mean food consumption, a response to

Table 5. Salmo salar. Mean value (SE) of physiological and haematological parameters for individual Atlantic salmon without lice infection (control) and at 12, 21 and $30 \mathrm{~d}$ post-infection. $\mathrm{LDH}=$ lactate dehydrogenase; $\mathrm{AP}=$ alkaline phosphatase. Means with the same letters were not significantly different from each other at the $5 \%$ level

\begin{tabular}{|c|c|c|c|c|}
\hline & \multicolumn{4}{|c|}{ Pooled data from all fish sampled } \\
\hline & Control & $12 \mathrm{~d}$ p.i. & $21 \mathrm{~d}$ p.i. & $30 \mathrm{~d}$ p.i. \\
\hline Haematocrit $(\%)$ & $44.3^{a}(4.5)$ & $51.8^{\text {व }}(9.9)$ & $35.6^{\mathrm{b}}(3.8)$ & $43.3^{\mathrm{ab}}(7.2)$ \\
\hline Leucocrit $(\%)$ & $0.9^{a}(0.4)$ & $1.2^{\mathrm{a}}(0.6)$ & $1.5^{\mathrm{d}}(0.3\}$ & $1.6^{\mathrm{d}}(0.4\}$ \\
\hline Osmolarity ( $\mathrm{mmol} \mathrm{l}^{-1}$ ) & $393^{\mathrm{a}}(45)$ & $389^{d}(40)$ & $323^{\prime \prime}(39)$ & $370^{\star}(52)$ \\
\hline Potassium (mmol l-1) & $1.4^{\mathrm{a}}(0.8)$ & $1.1^{\mathrm{a}}(0.5)$ & $3.5^{b}(0.6)$ & $1.2^{\mathrm{a}}(0.7)$ \\
\hline Sodium (mmol l-1) & $197.4^{\circ}(5.6)$ & $199.3^{\circ}(5.0)$ & $186.8^{b}(5.9)$ & $181.8^{b}(5.6)$ \\
\hline Cholesterol $\left(\mathrm{mmol} \mathrm{l}^{-1}\right)$ & $9.1^{\mathrm{cb}}$ & $9.7^{b}(1.5)$ & $5.2^{\alpha}(2.7)$ & $8.6^{\mathrm{ab}}(4.3)$ \\
\hline Albumin $\left(\mathrm{g} \mathrm{l}^{-1}\right)$ & $23.3(4.6)$ & $21.4^{\mathrm{a}}(2.5)$ & $12.9^{b}(2.1)$ & $22.1^{\mathrm{d}}(5.9)$ \\
\hline Protein $\left(\mathrm{g} \mathrm{l}^{-1}\right)$ & $50.7^{\circ}(5.0)$ & $53.0^{\mathrm{a}}(4.9)$ & $35.4^{\mathrm{b}}(6.4)$ & $54.8^{\circ}(12.6)$ \\
\hline Chloride $\left(\mathrm{mmol} \mathrm{l}^{-1}\right)$ & $135.3^{t}(3.5)$ & $137.2^{\circ}(2.8)$ & $140.7^{\circ}(11.8)$ & $132.0^{ \pm}(4.1)$ \\
\hline Calcium (mmol l-1) & $4.1^{\star}(0.9)$ & $4.1^{\circ}(0.5)$ & $3.3^{\circ}(0.7)$ & $3.8^{d}(0.9)$ \\
\hline Glucose $\left(\mathrm{mmol} \mathrm{l}^{-1}\right)$ & $3.5^{4}(1.6)$ & $3.7^{\circ}(1.2)$ & $4.9^{\circ}(1.3)$ & $4.9^{a}(1.0)$ \\
\hline $\operatorname{LDH}\left(\mathrm{u} \mathrm{l}^{-1}\right)$ & $600^{d}(72)$ & $430^{2 b}(110)$ & $321^{b}(38)$ & $440^{\mathrm{ab}}(89)$ \\
\hline $\operatorname{AP}\left(\mathrm{uI}^{-1}\right)$ & $440^{\circ}(99)$ & $320^{a}(41)$ & $140^{\mathrm{b}}(32)$ & $200^{b}(74)$ \\
\hline
\end{tabular}


stress (Jobling \& Wandsvik 1983, Abbott \& Dill 1985), in the infected groups of fish was recorded and correlated with the appearance of severe head erosions and changes in the physiological integrity of the fish. The head and operculum are particularly vulnerable areas because of the thinness of the skin and lack of scales (Jónsdóttir et al. 1992). Settlement along the dorsal ridge may be attributed to homing on water currents (Kabata \& Cousens 1973, Anstensrud \& Schram 1988) or promoted by the search for protection from these currents (Bron et al. 1991). Secondary bacterial and viral infections associated with such skin erosions are common causes of death in farmed fish (Wootten et al. 1982, Pike 1989), but evidence of such damage is rarely found for wild fish. Mechanical damage to the head and operculum of the fish, corresponding with the appearance of the preadult I, may lead to osmoregulatory failure less than $3 \mathrm{~d}$ after the appearance of the preadults, and 30 to 40 mobile lice have been reported to kill Atlantic salmon smolts (Grimnes \& Jackobsen 1996). However, the mortal impact of lice infections probably is dependent on the size of the fish and time of seawater residence as, in the present experiment, fish had a mean abundance of 51.5 lice at $21 \mathrm{~d}$ p.i. and no mortalities were recorded.

Osmoregulatory failure is associated with an increase in chloride levels, hyperproteinaemia (Grimnes \& Jakobsen 1996) and a decrease in osmolarity (Wedemeyer \& McLeay 1981). The range of chloride levels in the control fish in the present experiment were similar to previously reported chloride levels of 130 to $150 \mathrm{mmol}^{-1}$ for Atlantic salmon (Sigholt \& Finstad 1990 ) but these levels can vary, as slightly lower levels of 120 to $140 \mathrm{mmol}^{-1}$ have been recorded for Atlantic salmon (Bergheim et al. 1990, Bakke et al. 1991). Normal total protein and serum albumin levels, important for water balance (Wedemeyer \& Yasutake 1977), in Atlantic salmon also have been reported (Sandnes et al. 1988, Waagbo et al. 1988) and the results for total protein and serum albumin levels in the control fish were within these ranges. However, in the infected fish, total protein and serum albumin decreased significantly from the control groups at $21 \mathrm{~d}$ p.i. and chloride levels were elevated at $21 \mathrm{~d}$ p.i. This coincided with the appearance and repair of severe skin damage at Day 21 p.i., indicating that changes in the physiological integrity of the infected fish were due to leakage of these parameters from the skin erosions.

Sodium and cholesterol levels decreased significantly as compared to the control groups at $21 \mathrm{~d}$ p.i. The effects of stress on ionic regulation are normally determined by measuring plasma cortisol and sodium concentrations, and a reversible depletion in cholesterol is a secondary response to acute and chronic stress in fish (Wedemeyer \& McLeay 1981). These changes may be due to a stress response from the infected fish, but also may be a result of physical leakage from the head erosions at Day 21 p.i. Blood glucose levels were elevated in the infected fish throughout the experiment. Alkaline phosphatase and lactate dehydrogenase both decreased significantly as compared to the control at $21 \mathrm{~d}$ p.i. The decrease in enzyme concentration in the serum may be due to physical leakage of the enzymes from the erosions caused by the feeding activities of mobile lice. However, potassium increased, suggesting a possible imbalance between extracellular and intracellular components, although the increase in potassium could simply have come from the environment if leakage was occurring.

Haematocrit decreased significantly as compared to the control groups at $21 \mathrm{~d}$ p.i., coinciding with preadult and adult lice and their associated pathology. This is consistent with the work of Grimnes \& Jakobsen (1996), who found a decrease in haematocrit less than $3 \mathrm{~d}$ after the onset of the preadult stage, probably due to the increase in plasma ions causing either osmotic shrinking of erythrocytes or leakage of blood components. The measurement of hypoproteinaemia confirms that anaemia is probably due to membrane damage and leakage of blood components (Grimnes \& Jakobsen 1996)

No significant changes were found in the leucocrit throughout the study. Wedemeyer et al. (1990) used ventilation frequency, plasma glucose and leucocrit as indicators of stress. These criteria have been applied to the study of disease susceptibility caused by the stress of social interactions in rainbow trout, where subordinate fish showed decreased leucocyte volume and plasma glucose levels (Peters et al. 1988), and both acute and chronic stressors have been shown to depress the number of circulating lymphocytes in teleost fish (Peters et al. 1980, 1988). However, Pickering \& Pottinger (1985) failed to demonstrate a correlation in the number circulating lymphocytes and cortisol levels, confirming that, under certain conditions, an increase in susceptibility to disease is not accompanied by a reduction in the number of lymphocytes. Further work is needed on the effects of both acute and chronic stress on the ability of the fish to mount an immune reponse.

As the lice moulted through to adults at $30 \mathrm{~d}$ p.i., suppression of appetite, severe skin pathology and detrimental changes in the physiological integrity of the fish recovered. Hence, even though fish were still infected with lice, the mortal impact of the lice infection was reduced. Changes in serum electrolytes and physiological parameters associated with skin damage most likely were caused by leakage of electrolytes due to the feeding activities of the preadult lice, as they require food to increase in biomass between the moult 
from chalimus to preadults. As the lice became adults, the biomass of lice decreased, and as gravid females settled in a posterior location, the impact of the infection was reduced, allowing recovery of the head erosions and restoration of the physiological integrity. Furthermore, the impact of preadults was limited as the depressed food consumption at $21 \mathrm{~d}$ p.i. had no effect on either the specific growth rate or condition factor of the fish.

The use of radio-opaque markers in feed has been shown to be an accurate way of assessing individual food consumption in fish (Talbot 1985). In a social hierarchy, dominant fish consume a greater proportion of the daily meal (Fausch 1984, Huntingford et al. 1989, Metcalfe et al. 1989) and, once the dominance hierarchy is established, available evidence suggests that it tends to be stable (Jenkins 1969, Bachmann 1984, Abbott \& Dill 1985). In the present study, the dominance hierarchy was stable in all groups of fish before infection with lice. After infection, although stable in the control group, the dominance hierarchy became unstable in the infected group, indicating that lice infection disrupted the social structure of the group. The stress parameters and leucocrit did not increase with increasing food consumption of fish within the groups either before or after infection. Possibly, the feeding hierarchy was not an effective stressor, the stress parameters chosen were not suitable indicators of stress or there was too much variation in the data to make useful correlations between food consumption and either leucocrit or glucose.

The intensity of lice infections on each of the sample days was not correlated with food consumption, specific growth rate or any of the haematological or physiological parameters measured, either before or after infection. Stress-induced immunosuppression due to social domination did not compromise subordinate fish sufficiently to render them more susceptible to lice infections. This contrasted with the findings of Peters et al. (1988), who demonstrated that the subordinate trout were contaminated more frequently with Aeromonas hydrophila and had higher levels of glucose and leucocrits than the dominant fish and concluded that social subordination causes impairment to the defence mechanisms against bacteria of rainbow trout, but this did not occur in the present study. In aquaculture, some Atlantic salmon carry heavier lice burdens than other fish (Anonymous 1997) and this may be a consequence of slower swimming speed or other health problems which may further compromise the host rather than reduced immunocompetence due to stress. However, the possibility of a stress-induced immunosuppression due to the transition from freshwater to seawater or disease, for example, must not be eliminated as a factor which may predispose fish to lice infections.
In conclusion, the level of lice infections was not correlated with food consumption or any of the physiological or haematological parameters measured. Chalimus did not cause osmoregulatory failure in infected Atlantic salmon and, undoubtedly, most of the damage leading to morbidity and mortality was caused by mobile lice. Grimnes \& Jakobsen (1996) reported detrimental physiological and electrolyte changes in liceinfected Atlantic salmon for preadult stages only as fish became moribund or died before preadults reached adults because of the high infection rate obtained in their experiment. This work has provided the first evidence that infected fish can recover from the detrimental changes caused by lice infection, even when they are still infected with lice, and if fish can survive the preadult stage of lice, then the mortal impact of lice infections is greatly reduced.

Acknowledgements. This work was funded though a CASE award to L. Dawson from the Biotechnology and Biological Sciences Research Council.

\section{LITERATURE CITED}

Abbott JC, Dill LM (1985) Patterns of aggressive attack in steelhead trout (Salmo gairdnert). Can J Fish Aquat Sci 42: $1702-1706$

Anonymous (1991) Report of the Sea Trout Working Group. Department of the Marine, Dublin

Anonymous (1997) Report of the workshop on the interactions between saimon lice and salmonids. Int Coun Explor Sea CM 1997/M:4 Ref:F

Anstensrud, M, Schram TA (1988) Host and site selection by larval stages and adults of the parasitic copepod Lernaenicus sprattae (Sowerby) (Copepoda, Pennellidae) in the Oslofjord. Hydrobiologia 167/168:587-595

Bachmann RA (1984) Foraging behaviour of free living wild and hatchery brown trout in a stream. Trans Am Fish Soc 113:1-32

Bakke H, Bjerknes, V, Øvreeide A (1991) Effects of rapid changes of salinity on the osmoregulation of post-smolt Atlantic salmon (Salmo salar). Aquaculture 96:375-382

Bergheim A, Kroglund F, Vatne DF, Rosseland BO (1990) Blood plasma parameters in farmed Atlantic salmon (Salmo salar) transferred to sea cages at eight to ten months. Aquaculture 96:375-382

Berland B (1993) Salmon lice on wild salmon (Salmo salar L.) in western Norway. In: Boxshall GA, Defaye DD (eds) Pathogens of wild and farmed fish: sea lice. Ellis Horwood, New York, p 179-187

Bron JE, Sommerville, C, Jones M (1991) The settlement and attachment of the early stages of the salmon louse, Lepeophtheirus salmonis (Caligidae: Copepoda) on the salmon host, Salmo salar. J Zool Lond 224:210-212

Fausch KD (1984) Profitable stream positions for salmonids: relating specific growth rate to net energy gain. Can J Zool 62:441-455

Grimnes, A, Jakobsen PJ (1996) The physiological effects of salmon lice infection on post-smolt of Atlantic salmon. J Fish Biol 48:1179-1194

Huntingford FA, Kadri S, Metcalfe NB, Thorpe JE (1989) The 
feeding behaviour of salmon in sea cages. MS Rep. Scottish Salmon Growers Assoc, Glasgow

Jenkins TM Jr (1969) Social structure, position choice and micro-distribution of two trout species (Salmo trutta and Salmo gairdneri) resident in mountain streams. Anim Behav Mono 2:56-123

Jobling, M, Wandsvik A (1983) Effect of social interactions o growth rates and conversion efficiency of Arctic charr, Salvelinus alpinus L. J Fish Biol 22:577-584

Jobling $M$, Christiansen JS, Jørgensen $E H$, Arnesen AM (1993) The application of x-radiography in feeding and growth studies with fish: a summary of experiments conducted on Arctic charr. Rev Fish Sci 1:223-237

Johnstone R (1981) Dye marking. Fish Farmer 4:24-25

Jónsdóttir H, Bron JE, Wootten, R, Turnbull JF (1992) The histopathology associated with the pre-adult and adult stages of Lepeophtheirus salmonis on the Atlantic salmon, Salmo salar L. J Fish Dis 15:521-527

Jørgensen EH, Jobling M (1990) Feeding modes in Arctic charr, Salvelinus alpinus L.: the importance of bottom feeding for the maintenance of growth. Aquaculture 86 : 379-385

Jørgensen EH, Jobling $M$ (1992) Feeding behaviour and effect of feeding regime on growth of Atlantic salmon, Salmo salar. Aquaculture 101:135-146

Jørgensen EH, Jobling M (1994) Feeding and growth of exercised and unexercised juvenile Atlantic salmon in freshwater, and performance after transfer to sea water. Aquacult Int 2:154-164

Kabata, Z, Cousens B (1973) The structure of the attachment organ of Lernaeopodidae (Crustacea: Copepoda). J Fish Res Bd Can 29:1015-1013

McCarthy ID, Carter CG, Houlihan DF (1993a) The effect of feeding hierarchy on individual variability in daily feeding of rainbow trout, Oncorhynchus mykiss (Walbaum). J Fish Biol 41:257-263

McCarthy ID, Houlihan DF, Carter CG, Moutou K (1993b) Variation in individual food consumption rates of fish and its implications for the study of fish nutrition and physiology. Proc Nutr Soc 52:411-420

McLeay DJ, Gordon MR (1977) Leucorit: a simple haematological technique for measuring acute stress in salmonid fish, including stressful concentrations of pulpmill effluent. J Fish Res Bd Can 34:2164--2175

Metcalfe NB, Huntingford FA, Graham WD, Thorpe JE (1989) Early social status and development of life history strategies in Atlantic Salmon. Proc R Soc Lond B236:7-19

Peters G, Delventhal, H, Klinger H (1980) Physiological and morphological effects of social stress in the eel (Anguilla anguilla L.). Arch Fisch 30:157-180

Editorial responsibility: Wolfgang Körting,

Hannover, Germany
Peters G, Faisal M, Lang, T, Ahmed I (1988) Stress caused by social interaction and its effect on susceptibility to Aeromonas hydrophilia infection in rainbow trout Salmo gairdneri. Dis Aquat Org 4:83-89

Pickering AD, Pottinger TG (1985) Cortisol can increase the susceptibility of brown trout, Salmo trutta L, to disease without reducing the white blood cell count. J Fish Biol 27. 611-619

Pike AW (1989) Lice-major pathogens of farmed and Atlantic Salmon. Parasitol Today 5:291-297

Ricker WE (1979) Growth rates and models. In: Hoar WS, Randall DJ, Brett JR (eds) Fish physiology, Vol VIII. Academic Press Inc, New York, p 677-743

Sandes K, Lie, $\varnothing$, Waagbø R (1988) Normal ranges of some blood chemistry parameters in adult farmed Atlantic salmon, Salmo salar. J Fish Biol 32:129-136

Sigholt, M, Finstad B (1990) Effect of low temperature on sea water tolerance in Atlantic salmon (Salmo salar) smolts. Aquaculture 84:167-172

Stead SM, Houlihan DF, McLay HA, Johnstone R (1996) Effect of ration and seawater transfer on food consumption and growth of Atlantic salmon (Salmo salar) smolts. Can J Aquat Sci 53:685-692

Talbot C (1985) Laboratory methods in fish feeding and nutritional studies. In: Tytler P, Calow P (eds) Fish energetics: new perspectives. Croom Helm, London, p 125-154

Talbot, C. Higgins PJ (1983) A radiographic method for feeding studies on fish using metallic iron powder as a marker. J Fish Biol 23:211-220

Waagbø. R., Sandes K, Espelid, S, Lie, Ø. (1988) Haematological and biochemical analyses of Atlantic salmon. Salmo salar L., suffering from coldwater vibriosis (Hitra disease). J Fish Dis 11:417-423

Wedemeyer GA, McLeay DJ (1981) Methods for determining the tolerance of fishes to environmental stressors. In: Pickering $\mathrm{AD}$ (ed) Stress and fish. Academic Press, London, p 247-275

Wedemeyer GA, Yasutake WT (1977) Clinical methods for the assessment of the effects of environmental stress on fish health. Tech Pap US Fish Wild Serv 89

Wedemeyer GA, Barton BA, McLeay DJ (1990) Stress and acclimation. In: Schreck CB, Moyle PB (eds) Methods for fish biology. American Fisheries Society, Bethesda, MD p $451-489$

Wilkinson L (1992) SYSTAT: the system for statistics. SYSTAT, Inc, Evanston, IL

Wootten R, Smith JW, Needham EA (1982) Aspects of the biology of parasitic copepods, Lepeophtheirus salmonis and Caligus elongatus on farmed salmonids and their treatment. Proc R Soc Edin 81B:185-197

Submitted: June 30, 1998; Accepted: September 30, 1998 Proofs received from author(s): January 21, 1999 